\title{
6. EARLY CRETACEOUS MOLLUSKS FROM DSDP HOLE 397A OFF NORTHWEST AFRICA
}

\author{
Jost Wiedmann, Institut für Geologie und Paläontologie, Universität Tübingen, Federal Republic of Germany
}

\begin{abstract}
Macrofossil remains in Hole 397A off Cape Bojador, Tarfaya Basin, provide additional information about marine Lower Cretaceous biostratigraphy and paleoenvironment. The ammonites have been referred to Neocomites gr. N. neocomiensis (d'Orbigny); Phylloceras (Hypophylloceras) thetys diegoi (Boule, Lemoine, and Thevenin); and Protetragonites $\mathrm{cf}$. P. crebrisulcatus (Uhlig). Although these are all long-ranging species groups, their combination support a late Hauterivian age. One bivalve (Legumen? sp.) and one gastropod remain (incertae sedis) are figured.

The marine conditions of the off-shore Hauterivian are in contrast to the Wealden-like terrigenous sedimentation in the on-shore Lower Cretaceous of the Tarfaya Basin, where an initial marine transgression can be recognized in the uppermost Aptian. The ammonites point to deep basinal, Tethyan relationships.
\end{abstract}

\section{INTRODUCTION}

There has been increasing interest in the study of macrofossils from drilled deep-sea sites (e.g., Renz, 1972; Kauffman, 1976). At Hole 397A, several poorly preserved macrofossil remains were recovered which, nevertheless, were worthy of study.

At first, only four relatively well-preserved specimens of mollusks were treated. Two ammonites and one bivalve were roughly determined; one gastropod fragment, however, remained undeterminable. Unfortunately, these two ammonites were referred to conservative species groups of phylloceratids and lytoceratids, providing only an approximate biostratigraphic zonation. According to their evolutionary degree, they were placed (tentatively) in the Barremian. Thereafter, another ammonite was found in the cores, which is of the genus Neocomites (a genus that became extinct during the late Hauterivian). Therefore, the lower part of Hole 397A was dated as late Hauterivian near to or even grading into the lowermost Barremian.

The ammonites are of some value for determining the environmental interpretations and biogeographic relationships of the Lower Cretaceous off Cape Bojador. Another point of interest is the random preservation, especially compared with that of recently studied macrofaunas of comparable ages, sediments, and depth from the South Atlantic Leg 40 (Wiedmann and Neugebauer, in press).

\section{AGE DETERMINATION}

All ammonites recovered, unfortunately, belong to long-ranging species groups. Nevertheless, some age refinement seems to be possible after preparation of these specimens, especially their suture lines. The com- bination of all data permits an appropriate age determination.

The stratigraphically more important specimen of the first sample is the lytoceratid (Plate 1, Figures 2, 7) from Sample 39-2, CC. It belongs to the group of Protetragonites quadrisulcatus (d'Orbigny) ranging throughout the complete Early Cretaceous (Wiedmann, 1962). By its degree of involution and course of constrictions, the present specimen can be related more precisely to Protetragonites crebrisulcatus (Uhlig) of the Barremian (and early Aptian).

The phylloceratid specimen (Plate 1, Figures 1, 6) occurs in Sample 46-3, 93-94 cm. It is referred to the group of Phylloceras (Hypophylloceras) thetys (d'Orbigny), as defined by Wiedmann (1964). This group also has a lengthy temporal range, from the Berriasian to the early Cenomanian. The suture line of the deepsea specimen, however, is that of the subspecies $P h$. $(H$.) thetys diegoi Boule, Lemoine, and Thevenin (Wiedmann, 1964, fig. 38), ranging from the Barremian to the early Cenomanian. From the first available sample, a Barremian age was postulated.

An additional ammonite was recovered, in Sample $42-1,74-76 \mathrm{~cm}$, that can be attributed to the group of Neocomites neocomiensis (d'Orbigny) of Valanginian to early Hauterivian age. Because this specimen has the best preservation, reworking can be excluded. There is no contradiction to an overlap of these three long-ranging species or subspecies during the late Hauterivian. This is the same age as derived from the nannofossil and microfossil records (Čepek and Wind, this volume; Lutze, this volume). It is interesting that some foraminifera seem to support a younger age, i.e., Barremian to early Aptian (Basov, this volume). In any case the Cretaceous part of Hole 397A is to be placed near the 
Hauterivian-Barremian boundary and may even grade into the latter stage.

\section{SHELL PRESERVATION}

At first glance, all specimens seemed to be perfectly preserved. On the steinkerns, generally, the original aragonitic shell is present. In some instances (e.g., Plate 1, Figure 5), no or little sediment was deposited within the shell, most probably due to a relatively high rate of sedimentation. While the original shell material is perfectly preserved in some instances, it is partially dissolved in others (e.g., Plate 1, Figure 2). From this specimen, only the left part (which apparently is provided with shell) was visible outside the sediment. During the cleaning of sediment from the right half of the outer whorl and the inner whorls, we observed that no shell material in this region was preserved between steinkern and sediment. This made preparation extremely difficult and led to the "weathered" aspect of this part of the shell. Suture lines and septa are not preserved in this part of the shell, while they exhibit perfect preservation in those parts covered with the original shell (Plate 1, Figures 1, 2). In Figure 1, they are visible even through the transparent innermost shell layers. The selective dissolution pattern is hard to explain, especially since the best nannofossil preservation is found in Cores 42,46 , and 47 (Wind, personal communication). The reworking of ammonites can be excluded as a result of the perfect preservation of fragile shell material. Shell fragmentation (Plate 1, Figure 4 ), however, is obviously related to sedimentary compaction. Nevertheless, the shells are found to be coherent in most cases. Whether the fragmented preservation of two specimens (Plate 1, Figures 1,3 ) is due to the above-mentioned shell dissolution or to transportation effects cannot be decided from the poor material available. The possibility of wave or current activity must be considered.

\section{PALEOENVIRONMENT}

Little can be concluded from these few specimens about paleoenvironment and paleogeography. It is interesting, however, that well-ornamented trachyostraceous species, which generally are regarded as inhabitants of the epicontinental and shelf seas, are absent in these core samples. Neocomites is an exception that favors the basinal Tethyan environments. This is especially true for the leiostraceous (smooth) phylloceratids and lytoceratids. Although it is difficult to judge from only three specimens, and although there were Wealden-like conditions in the on-shore Tarfaya Basin at the same time, the ammonites point to an open basin Tethyan environment rather than to shelf or epicontinental sea conditions where ornamented species should prevail (Wiedmann, 1973).

\section{SYSTEMATIC DESCRIPTIONS}

Phylum MOLLUSCA

Class CEPHALOPODA

\section{Order AMMONOIDEA}

\section{Suborder PHYLLOCERATINA Arkell, 1950}

Family PHYLLOCERATIDAE Zittel, 1884

Genus PHYLLOCERAS Suess, 1865

Subgenus HYPOPHYLLOCERAS Salfeld, 1924

Phylloceras (Hypopylloceras) thetys diegoi Boule, Lemoine, and Thevenin, 1906

(Plate 1, Figures 1, 6)

1906 Phylloceras Diegoi Boule, Lemoine, and Thevenin, p. 10, textfig. 4; pl. 1, fig. 5,7 .

$1964 \mathrm{Ph}$. (H.) thetys diegoi Boule, Lemoine, and Thevenin. Wiedmann, p. 172, text-fig. 38; pl. 12, fig. 7, 5 (and for synonymy).

Material: One fragmentary chambered specimen (GPIT ${ }^{1}$ 1519/ 1) from Sample $46-3,93-94 \mathrm{~cm}$. The specimen is laterally crushed and has an approximate whorl height of $8 \mathrm{~mm}$.

Remarks: By its relatively open umbilicus (Plate 1, Figure 1) and especially its suture line (Plate 1, Figure 6) with clearly diphyllic saddle $E L$ and $L U_{2}$, the specimen easily can be related to the species group of Hypophylloceras thetys, as previously defined (Wiedmann, 1964). It has to be included in the type species of this group, ranging from the Berriasian to the lower Cenomanian, if $P h$. majoricense Wiedmann and $P h$. diegoi Boule, Lemoine, and Thevenin are included as subspecies. Comparison of suture lines shows the nearest relationships of the present specimen to the hypotype of $P h$. $(H$.) thetys diegoi from the Aptian of Mallorca, as figured by Wiedmann (1964, text-fig. 38). Wiedmann gives the complete synonymy of the subspecies, in which the deep-sea specimen now is included.

$P h$. (H.) thetys diegoi is known from the Barremian of Algeria, from the Caucasian and Balearic Aptian and Albian, and from the Cenomanian of Madagascar. Now the upper Hauterivian of the Atlantic off South Morocco can be added; this is not surprising, since the subspecies deviates from $P h$. (H.) thetys thetys of the lowermost Cretaceous.

Suborder LYTOCERATINA Hyatt, 1889

Family LYTOCERATIDAE Neumayr, 1875

Genus PROTETRAGONITES Hyatt, 1900

Protetragonites cf. P. crebrisulcatus (Uhlig, 1883)

(Plate 1, Figures 2, 7)

cf. 1962 Protetragonites crebrisulcatus (Uhlig). Wiedmann, p. 19, pl. 1 , fig. 3 ; pl. 3, fig. 2,4 (for synonymy).

Material: One dwarfed specimen (GPIT 1519/2) from Sample $39-2$, CC. The specimen has a diameter of $10.5 \mathrm{~mm}$ and is chambered throughout, thus representing a phragmocone.

Remarks: This form belongs to the Lower Cretaceous species group of Protetragonites quadrisulcatus (d'Orbigny) as defined by Wiedmann (1964), including the previous genus "Hemitetragonites" (Spath, 1927) with its type species "H." crebrisulcatus. The deep-sea specimen doubtfully can be referred to the latter species, since it is somewhat more involute than $P$. quadrisulcatus; the constrictions are less pronounced, more common, not equally spaced, and more convex instead of being concave (Plate 1, Figure 2).

The suture line (Plate 1, Figure 7) in its simple character seems to agree more with $P$. quadrisulcatus than with $P$. crebrisulcatus, but this is due to the small size of the present specimen where the suture line has been drawn at a whorl height of $2 \mathrm{~mm}$. H. crebrisulcatus is a common species of Tethyan Barremian, locally ranging into the Aptian (Anthula, 1899; Wiedmann, 1962). As in the previous species, the late Hauterivian age of the deep-sea specimen is not unexpected, since the Barremian species is directly related to the mostly Valanginian $P$. quadrisulcatus.

${ }^{1}$ Geo.-Paläont. Institute Universităt Tübingen. 
Suborder AMMONITINA Hyatt, 1889

Superfamily PERISPHINCTACEAE Steinmann, 1890

Family BERRIASELLIDAE Spath, 1922

Genus NEOCOMITES Uhlig, 1905

Neocomites gr. N. neocomiensis (d'Orbigny, 1841) (Plate 1, Figure 5)

cf. 1841 Ammonites neocomiensis d'Orbigny, p. 202, pl. 59, fig. 8-10.

Material: One specimen (GPIT 1519/5) from Sample 42-1, 74$76 \mathrm{~cm}$ has a diameter of $14.5 \mathrm{~mm}$ and seems to be chambered throughout. Due to the collapsed shell preservation, the specimen is very fragile, and only partially preserved on each of the two casts (Plate 1, Figures 5a, b).

Remarks: The shell clearly shows all properties of the inner whorls of specimens of the Neocomites neocomiensis group: a largely closed umbilicus, small tubercles at the umbilical margin, subordinated ribbing due to the small diameter, and a much higher number of tubercles at the external margin. No suture line can be observed; only relics of the septa are visible and permit recognition that the specimen is chambered throughout and, thus, is a phragmocone.

Due to the poor preservation, however, definitive determination would be inappropriate.

$N$. neocomiensis is known from the Tethyan, central European and Madagascan Valanginian, and early Hauterivian. The deep-sea specimen off South Morocco is the first citation of this species group from a late Hauterivian interval.

\section{Class BIVALVIA}

Family VENERIDAE Rafinesque, 1815

Genus LEGUMEN Conrad, 1858

Legumen? sp.

(Plate 1, Figure 4)

Material: One specimen (GPIT 1519/4) from Sample 50-5, 21$22 \mathrm{~cm}$ is double-valved, but cut at the posterior margin.

Remarks: The nearly perfectly preserved specimen has an elongate outline, measuring $11.5 \mathrm{~mm}$ in length and $6.8 \mathrm{~mm}$ in height. The dorso-anterior margin is straight; the dorso-posterior margin was cut, unfortunately, during the sampling. It is longer than the anterior part of the valve, which is covered by fine concentric striae. The valves are only moderately inflated, even before compaction.

All characters agree with those of the genus Legumen to which the specimen only doubtfully is referred, since its internal features are unknown.

Legumen is a common form in the European, American, and Indian Cretaceous.

\section{Class GASTROPODA}

gastropod debris, indet.

(Plate 1, Figure 3)

Material: One fragment (GPIT 1519/3) from Sample 39-2, CC.
Remarks: A very fragmentary part of a gastropod whorl permits inclusion of this group in the macrofauna of Hole $397 \mathrm{~A}$, but does not require specific or generic determination. In addition to the labial ridge, the shell shows a fine reticulate growth pattern.

\section{ACKNOWLEDGMENTS}

I am much indebted to Dr. U. von Rad for his efforts in selecting and making available the macrofossil remains considered in this study.

\section{REFERENCES}

Anthula, D. J., 1899. Über die Kreidefossilien des Kaukasus, Beitr. Palaeont. Geol. Oesterr.-Ungarns u. Orients, v. 12, p. 53-159.

Boule, M., Lemoine, P., and Thevenin, A., 1906. Céphalopodes crétacés des environs de Diego-Suarez I, Paléontol. Madagascar, Ann. Paléontol., v. 1, p. 173-192.

Kauffman, E. G., 1976. Deep-sea Cretaceous macrofossils: Hole 317A, Manihiki Plateau. In Schlanger, S. O., Jackson, E. D., et al., Initial Reports of the Deep Sea Drilling Project, v. 33: Washington (U.S. Government Printing Office), p. 503-528.

d'Orbigny, A., 1841. Paléontologie française. Terrain Crétacé. I. Céphalopodes. Second part, p. 121-430.

Renz, O., 1972. Aptychi (Ammonoidea) from the Upper Jurassic and Lower Cretaceous of the western North Atlantic (Site 105, Leg 11, DSDP). In Hollister, C. D., Ewing, J. I., et al., Initial Reports of the Deep Sea Drilling Project, v. 11: Washington (U.S. Government Printing Office), p. 607-620.

Spath, L. F., 1927. Revision of the Jurassic cephalopod faunas of Kachh (Cutch), India geol. Surv. Mem., Palaeontol. indica, new ser., v. 9, mem. 2, p. 1-945.

Uhlig, V., 1883. Die Cephalopodenfauna der Wernsdorfer Schichten, Denkschr. k. k. Akad. Wiss. Wien, math.-naturw. Kl., v. 46, p. 127-290.

Wiedmann, J., 1962. Unterkreide-Ammoniten von Mallorca. 1. Lytoceratina, Aptychi, Abh.Akad.Wiss. u. Liter., math.naturw. $K l$., v. 1962 , p. 1-148.

1964. Unterkreide-Ammoniten von Mallorca. 2. Phylloceratina, Abh. Akad. Wiss. u. Liter., math. -naturw. Kl., v. 1963 , p. $149-264$.

1973. Evolution or revolution of ammonoids at Mesozoic system boundaries, Biol. Rev., v. 48, p. 159-194.

Wiedmann, J. and Neugebauer, J., in press. Lower Cretaceous Ammonites from the South Atlantic Leg 40 (DSDP), their stratigraphic value and sedimentologic properties. In Bolli, H. M., Ryan, W. B. F., et al., Initial Reports of the Deep Sea Drilling Project, Supplement to Volumes 38, 39, 40, and 41: Washington (U.S. Government Printing Office), p. 709-727. 


\section{PLATE 1}

Figure 1

Figure 2

Figure 3

Figure 4

Figure 6

Figure 7
Figure 5a,b Neocomites gr. N. neocomiensis (d'Orbigny).

Phylloceras (Hypophylloceras) thetys diegoi Boule, Lemoine, and Thevenin. Hypotype, GPIT $1519 / 1$. Lateral view of chambered fragment. $6 / 1$. Sample 46-3, 93-94 cm, upper Hauterivian.

Protetragonites cf. $P$. crebrisulcatus (Uhlig). Doubtful hypotype, GPIT 1519/2. Lateral view of chambered immature specimen. 4/1. Sample 39-2, CC, upper Hauterivian.

Gastropod debris, indet. GPIT 1519/3.2/1 Sample 39-2, CC, upper Hauterivian.

Legumen ? sp. Specimen GPIT 1591/4. Left valve with cut off dorso-posterior margin; arrow indicates position of beak. 3/1. Sample 50-5, 21-22 cm, upper Hauterivian. Doubtful hypotype, GPIT 1519/5. The crushed specimen is partially preserved in the counterpart. 3/1. Sample 42-1, 74-76 cm, upper Hauterivian.

Same as Figure 1. Suture line, at whorl height of $8 \mathrm{~mm}$. About $10 / 1$.

Same as Figure 2. Suture line, at whorl height of $2 \mathrm{~mm}$. About $30 / 1$. 
PLATE 1
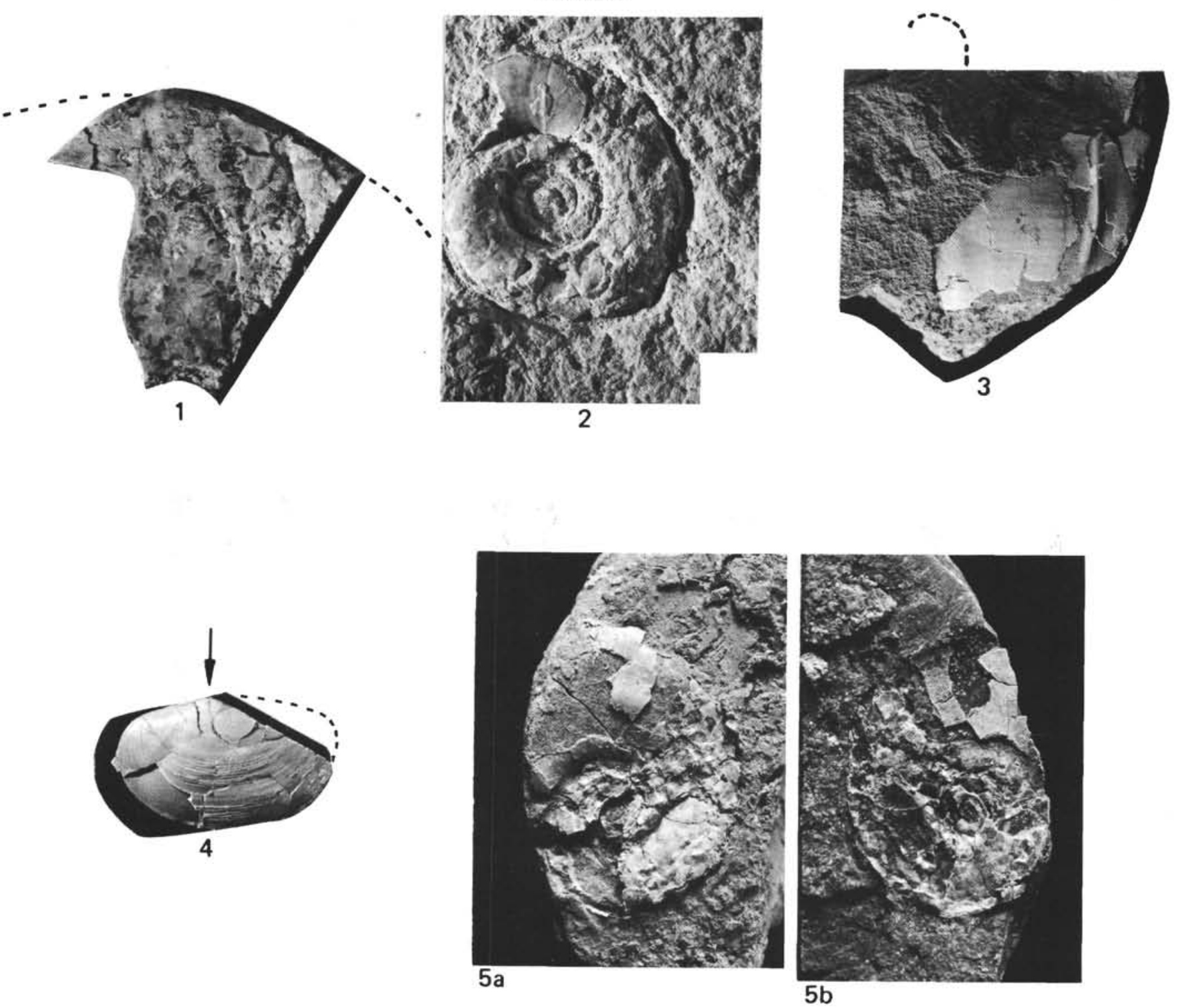

6

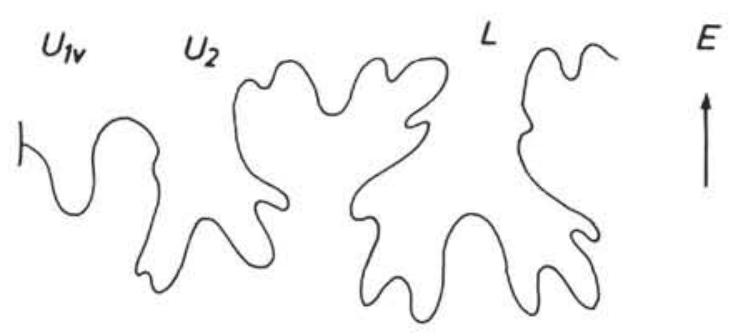

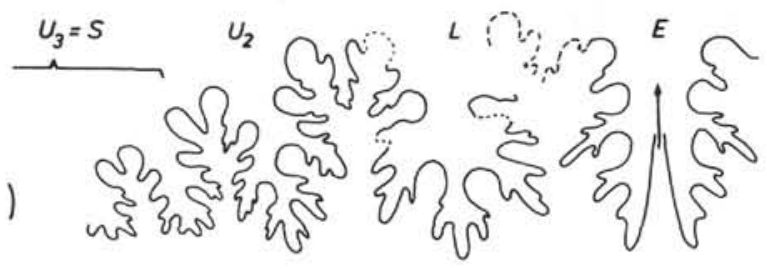

